DOI: $10.26693 / \mathrm{jmbs} 05.04 .145$

UDC 616.1-004-036:616.379-008.64

Zhuravka N. V., Shop I. V, Folusho E. T.

\title{
THE DEVELOPMENT OF ATHEROSCLEROSIS IN PATIENTS WITH DIABETES MELLITUS
}

\author{
V. N. Karazin Kharkiv National University, Ukraine
}

zhuravkanata@gmail.com

Features of the development of atherosclerosis in a patient with diabetes mellitus are presented in this article on the example of a clinical case. Atherosclerotic changes progress not only faster, but also earlier in patients with diabetes mellitus, while reducing their life expectancy. Patients with diabetes are characterized by an increased risk of developing cardiovascular disease. A feature of diabetes mellitus contributing to this is the accelerated atherosclerosis. In patients with diabetes mellitus, compared with patients without this disease, even though normal levels of low-density lipoprotein cholesterol in the blood are achieved, the progress of atherosclerotic changes is associated with poor glycemic control.

The purpose of the study was to analyze the features of the course of coronary heart disease on the example of a clinical case of a patient with the rapid development of atherosclerosis.

Material and methods. A 55-year-old man was with complaints for dyspnea attacks at night, stopped in a sitting position, sometimes dyspnea attacks were accompanied by pain in the chest, transient rises of blood pressure, headaches. Anamnesis is remarkably significant for arterial hypertension $(\max 240 / 180 \mathrm{~mm}$ $\mathrm{Hg}$, adapted to $130-140 / 80 \mathrm{~mm} \mathrm{Hg}$ ), he took antihypertensive therapy. Three years in a row, the patient has had surgery for stenting of the coronary arteries. Clinical diagnosis: Ischemic heart disease. Stable angina, II functional class. Arterial hypertension, Il stage, 3 degree. Coronary vascular disease risk was very high. Atherosclerosis of the coronary arteries. Right coronary artery stenting (22.05.17), anterior descending artery stenting (13.12.18). Ventricular extrasystolic arrhythmia with episodes of unstable ventricular tachycardia. Heart failure III FC, stage C. Diabetes mellitus II type, insulin-dependent, severe degree, decompensation. Diabetic polyneuropathy. Obesity, III degree.

The article presents the analysis of the clinical case of a patient with coronary heart disease, expressed atherosclerosis with diabetes mellitus type 2 . In this regard, the issues of choosing the tactics of sugar-lowering therapy and the additive effect of drugs based on randomized clinical trials are discussed.
Conclusion. Atherosclerotic changes develop not only faster, but also earlier in patients with diabetes, while reducing their life expectancy. In patients with diabetes compared with those without this disease, even though a normal in cholesterol level of lowdensity lipoproteins in the blood achieved, poor glycemic control in patients with diabetes mellitus is associated with the progression of atherosclerotic changes.

Keywords: coronary artery disease, diabetes mellitus, cardiovascular risk factors, atherosclerosis.

Introduction. Coronary heart disease (CHD) is the most common cause of death worldwide. CHD consists of several clinical conditions characterized by myocardial ischemia, which is a situation of cardiomyocyte damage due to a reduced blood supply compared with their metabolic demand [1]. CHD is classically attributable to coronary vascular disease (CVD), a condition with the presence of an atherosclerotic plaque that causes a vascular obstruction of more than $50 \%$ cases. On the other hand, coronary micro vascular dysfunction, which is a condition of impaired vasomotor tone due to several mechanisms, is able to provoke $\mathrm{CHD}$, independently from the presence of an atherosclerotic plaque. In fact, clinical, angiographic, and autoptic findings suggest a multifaceted pathophysiology of CHD that should not be associated only with CVD [2].

Several cardiovascular risk factors are involved in the pathogenesis of CHD. Diabetes mellitus (DM) is considered one of the strongest risk factors for cardiovascular disease, including CHD, CVD, and peripheral arterial disease [3-6]. Patients with DM are at double the risk of CVD [7]. The most common cause of death among diabetic patients is CVD, so the risk of increased cardiovascular morbidity and mortality has been well described and diabetes has been named a "cardiovascular disease equivalent" [8].

Numerous studies have shown that patients with DM have accelerated atherosclerotic vascular disease, and major advances in understanding its pathogenesis have made [9-11]. Violation of glycemic homeostasis has a direct stimulating effect on the formation, increase in the number and size of 
atherosclerotic plaques. Factors that may play an important role in the more rapid progression of atherosclerosis in patients with DM: inflammation, neovascularization and hemorrhage inside plaques. As a result, patients with DM and CHD are subject to higher morbidity and mortality have compared with patients without diabetes. When assessing the significance of hyperglycemia, it must be borne in mind that it rarely occurs in the absence of other metabolic disorders, which have an independent impact in the development of CVD, but at the same time reinforce each other's adverse effects and require timely active correction. The situation significantly worsens with a combination of DM and arterial hypertension, especially in the absence of adequate treatment.

The purpose of the study was to analyze the features of the course of CHD on the example of a clinical case of a patient with the rapid development of atherosclerosis.

\section{Clinical case}

A 55-year-old man came to the cardiology clinic with complaints for attacks of dyspnea at night, stopped in a sitting position; sometimes dyspnea attacks are accompanied by pain in the chest; headaches amid increased blood pressure; numbness of the lower extremities, worse at rest. The symptoms progressively worsened. The patient had arterial hypertension $(\mathrm{AH})$ from the age of thirty $(\max 240 / 180 \mathrm{~mm}$ $\mathrm{Hg}$, adapted to $130-140 / 80 \mathrm{~mm} \mathrm{Hg}$ ), he received antihypertensive therapy. Chest pains appeared about eight years ago. Three years ago during ECG monitoring, a pathological number of ventricular extrasystoles and paroxysms of unstable ventricular tachycardia were detected, the coronary angiography was followed by stenting of the right coronary artery. One year later due to the deterioration of the condition there was a re-coronary angiography followed by stenting of the anterior descending artery. A year later there condition of the patient worsened. That is why he came to a cardiology clinic for coronary angiography and treatment correction. His medical records showed obesity from the childhood and the development of DM type 2 for which he received metformin (500 mg twice daily) therapy; after the first surgery he was prescribed insulin therapy. He has no family history of CHD or DM. Upon physical examination, the patient was a good-looking middle-aged man with an obese physique (abdominal type of subcutaneous fat distribution). His height is $174 \mathrm{~cm}$, weight $120 \mathrm{~kg}$, BMI $=40 \mathrm{~kg} / \mathrm{m}^{2}$. His vital signs include a temperature of $36.8^{\circ} \mathrm{C}$, blood pressure of $142 / 83 \mathrm{~mm} \mathrm{Hg}$, respiratory rate of 15 breaths/min, and the heart rate of 87 beats/ min. He has a regular heart rhythm, heart sounds are muffled. His respirations are nonlabored, and his breath sounds are clear to auscultation bilaterally.
Upon abdominal examination, truncal obesity was observed. His abdomen is soft and not tender with normal bowel sounds. Pulsation on a. dorsalis pedis and a. tibialis posterior are reduced. There was an oedema of lower third of both shins. The rest of physical examination is unremarkable. Within this examination, a complete blood count showed erythrocytosis; fasting blood glucose was $17.95 \mathrm{mmol} / /$; Echocardiography: atherosclerotic cardiosclerosis, aorta atherosclerosis, LV hypertrophy; Electrocardiography (ECG): Atrial fibrillation with heart rate was 75-112/ min. Hypertrophy of the myocardium of the left ventricle. Subendocardial ischemia. Clinical diagnosis: Ischemic heart disease. Stable angina, II functional class. Arterial hypertension, II stage, 3 degree. CVD risk very high. Atherosclerosis of the coronary arteries. Right coronary artery stenting (22.05.17) anterior descending artery stenting (13.12.18) Ventricular extrasystolic arrhythmia with episodes of unstable ventricular tachycardia. Heart failure III FC, stage C. Diabetes mellitus II type, insulin-dependent, severe degree, decompensation. Diabetic polyneuropathy. Obesity, III degree. We recommended the following treatment: lifestyle modification and diet should focus on losing weight in the first place, control of compliance to medical recommendations. Pharmacological treatment: insulin, bisoprolol $10 \mathrm{mg}$ per day, perindopril $4 \mathrm{mg}$ per day, rosuvastatin $10 \mathrm{mg}$ per day, acetylsalicylic acid in combination with clopidogrel in an equal dosage of $75 \mathrm{mg}$ each once a day, pantoprazole $20 \mathrm{mg}$ per day for 10 days of each month, torasemide $10 \mathrm{mg} 1$ time in 3 days, under the control of urea, creatinine and electrolytes.

The article presents the analysis of the clinical case of a patient with CHD, expressed atherosclerosis with DM type 2. In this regard, the issues of choosing the tactics of sugar-lowering therapy and the additive effect of drugs based on randomized clinical trials are discussed.

Patient signed patient informed consent, the study conducted in accordance to the Helsinki Declaration of the World Medical Association, the Statute of the Ukrainian Bioethics Association, the standard provisions on ethics of the Ministry of Health of Ukraine No. 66 dated February 13, 2006.

\section{Discussion}

According to published data, CVDs are the most common cause of death in patients with impaired carbohydrate metabolism worldwide, due to their earlier development of atherosclerosis [7]. Atherosclerosis in patients with DM has a number of features. It begins 20 years earlier compared to those with no diabetes, recognized even at the stage of impaired glucose tolerance, progresses much faster and proceeds in a more severe form, atherosclerotic lesion is bilateral 
polysegmental in nature, often localized in vessels of medium diameter [12]. DM, regardless of CAD and arterial hypertension, is the cause of direct damage to the heart muscle - diabetic cardiomyopathy, leading to impaired left ventricular function and the development of heart failure, arrhythmias and cardiac conduction disorders [13].

Modern approaches to the treatment of patients with diabetes suggest physiological control of glycaemia (lowering the level of glycosylated (glycated) hemoglobin to $6.5 \%$ or less) and reducing the influence of other risk factors for CAD, such as dyslipidemia, hypertension, obesity, smoking and nephropathy [7]. Patients with DM are at increased risk for repeat interventions and mortality after coronary angioplasty and stenting [14]. Therapies to lower lipids and blood pressure are proven interventions to reduce cardiovascular risk. There is strong evidence that acetylsalicylic acid, statins and angiotensin-converting enzyme (ACE) inhibitors reduce the risk of death from CVD in patients with DM [15, 16, 17]. In adults with DM and arterial hypertension, in case of the left ventricular hypertrophy, antihypertensive drug treatment should be initiated at a BP of $130 / 80 \mathrm{~mm} \mathrm{Hg}$ or higher with a treatment DBP: goal of less than $130 / 80 \mathrm{~mm} \mathrm{Hg}$. Drugs of choice are ACE inhibitors and ARBs which also have the best efficacy among the drug classes on urinary albumin excretion. Beta blockers must be used in patients in incidence of stroke or myocardial infarction and has heart failure to reduce mortality [18]. Considering the risk of developing hypoglycemia dangerous for the cardiovascular system in diabetes (especially with concomitant insulin therapy and taking non-selective beta-blockers), the use of beta-blockers in DM has its own characteristics. Therefore, the first choice of drugs is selective BAB (bisoprolol, metoprolol, nebivolol, etc.), its effect on glycaemia is much less pronounced than non-selective drugs.

Due to of the decompensation of DM, the patient was prescribed insulin therapy until it droped to normal values. Further consultation from an endocrinologist is recommended for the selection of an oral hypoglycemic drug.

In the discussed middle-aged patient of 55 years with III degree obesity and DM since the age of twenty, suffering from IHD, ventricular extrasystoles arrhythmia with episodes of unstable ventricular tachycardia, and with associated hypertension since the age of thirty, there was no significant difference in lipid profile from target levels. However, at the same time, over the last three years, coronary angiography was performed twice with subsequent stenting of the coronary arteries, which suggests the progression of the atherosclerotic process. Due to the chronic course of metabolic disorders in patients with diabetes, there was a constant progression of atherosclerosis, which led to widespread myocardial ischemia on the background of damage to several coronary arteries and determined a high incidence of restenosis. Even after successful revascularization, adequate control of cardiovascular risk factors is necessary. Relapse may be associated with the progression of stenosis of other coronary arteries. According to modern concepts, patients with diabetes 40 years of age and older should receive at least $81 \mathrm{mg}$ / day of aspirin unless contraindicated. All patients with ACS, both with elevated ST segment and without it, should receive acetylsalicylic acid medications from the first day of illness and for life, and the first 12 months after ACS there should be additionally one of the other antiplatelet agents, such as clopidogrel, ticagrelor or prasugrel (level of evidence A) [19]. Nevertheless, there is an alternative opinion that is the most safe for all patients from the point of view of developing complications from the hemostatic system. This is clopidogrel (level of evidence C) [19].

Special attention should be directed to correction of lipid metabolism disorders. According to the recommendations of the American diabetic association patients with CVD (CAD, peripheral artery disease, ischemic stroke, transient ischemic attack) are classified as the very high-risk group [20]. For this group, the goal should be set to lowering LDL-C to $<70 \mathrm{mg} / \mathrm{dL}$ or by more than $50 \%$ of the baseline level for secondary prevention. Furthermore, when acute coronary syndrome occurs, statin should be immediately administered regardless of the baseline LDL-C concentration. The 2018 AACE/ACE guidelines recommended to classify patients with atherosclerotic CVD and atherosclerotic CVD continuing to progress even after lowering LDL-C to $<70 \mathrm{mg} / \mathrm{dL}$, diabetes, stage 3 or 4 chronic kidney disease, heterozygous familial hypercholesterolemia (heFH), or history of premature atherosclerotic CVD (men < 55 years, women < 65 years) into the extreme risk group and to set the target for LDL-C to $<55 \mathrm{mg} / \mathrm{dL}$ [21]. In the absence of an adequate effect from the administration of statins in patients with coronary artery disease with diabetes, combination therapy with the addition ezetimibum (sequestrant of bile acids), prolonged-release nicotinic acid or fibrates can be prescribed.

Thus, it can be assumed that the process of coronary atherosclerosis progression in this patient could be triggered by not following the recommendations on a healthy lifestyle and not fulfilling medical appointments, metabolic disturbances on the background of obesity, DM decompensation, blood pressure levels exceeding the target values, and progression of proximal stenosis coronary arteries due to damage to the intima after primary endovascular intervention. 


\section{Conclusion}

Cardiovascular diseases, and primarily CHD, are the main cause of death in patients with diabetes. In diabetes, atherosclerosis is aggressive. Atherosclerotic changes develop not only faster, but also earlier in patients with diabetes, while reducing their life expectancy. The mechanisms for the rapid progression of atherosclerotic vascular lesions in diabetes are multicomponent and are not yet completely clear. Their study creates the prerequisites for the development of new therapeutic strategies for the prevention of diabetes-associated cardiovascular diseases. To prevent coronary complications of diabetes, glycemic control alone is not enough. In patients with DM compared to those without this disease, even though a normal cholesterol level of low-density lipoproteins in the blood is achieved, poor glycemic control is associated with the progression of atherosclerotic changes. A comprehensive, active correction of all significant risk factors (hyperglycemia and insulin resistance, hypertension, dyslipidemia) and preventive therapy with antiplatelet agents are required.

Thereby, the progression of coronary atherosclerosis in this patient can be triggered by diabetes mellitus, which served the basis for the rapid development of more severe cardiovascular diseases. Particular attention in this category of patients should be given to timely and earlier treatment with an emphasis on the beginning of combination therapy: hypotensive, hypolipidemic, hypoglycemic. This approach is justified to prevent the development of complications in these patients.

\section{References}

1. Lanza GA, Crea F. Cardiopatia ischemica. In: Medicina Interna Sistematica. 6th ed. Vol 1. Milan, Italy: Elselvier Italia srl; 2010. p. 103-49.

2. Kalofoutis C, Piperi C, Kalofoutis A, Harris F, Phoenix D, Singh J. Type II diabetes mellitus and cardiovascular risk factors: Current therapeutic approaches. Exp Clin Cardiol. 2007; 12(1): 17-28.

3. World Health Organization. Global Report on Diabetes. Geneva, Switzerland: World Health Organization; 2016.

4. Wang CCL, Hess CN, Hiatt WR, Goldfine AB. Clinical Update: Cardiovascular Disease in Diabetes Mellitus. Circulation. 2016; 133: 2459-502. doi: 10.1161/CIRCULATIONAHA.116.022194

5. Selvin E, Steffes MW, Zhu H, Matsushita K, Wagenknecht L, Pankow J, et al. Glycated hemoglobin, diabetes and cardiovascular risk in nondiabetic adults. N Engl J Med. 2010; 362: 800-11. doi: 10.1056/NEJMoa0908359

6. Santos-Oliveira R, Purdy C, da Silva MP, dos Anjos Carneiro-Leao AM, Machado M, Einarson TR. Haemoglobin A1c levels and subsequent cardiovascular disease in persons without diabetes: A meta-analysis of prospective cohorts. Diabetologia. 2011; 54: 1327-34. doi: 10.1007/s00125-011-2078-8

7. Mogensen CE. New treatment guidelines for a patient with diabetes and hypertension. J Hypertens Suppl. 2003; 21 S25-S30.

8. Sarwar N, Gao P. Emerging Risk Factors Collaboration. Diabetes mellitus, fasting blood glucose concentration, and risk of vascular disease: A collaborative meta-analysis of 102 prospective studies. Lancet. 2010; 375: 2215-22. doi: 10.1016/S0140-6736(10)60484-9

9. Third Report of the National Cholesterol Education Program (NCEP) Expert Panel on Detection, Evaluation, and Treatment of High Blood Cholesterol in Adults (Adult Treatment Panel III) Final Report. Circulation. 2002; 106: 3143-421.

10. Berthezène F. Diabetic dyslipidaemia. Br J Diabetes Vasc Dis. 2002; 2(Suppl 1): S12-7.

11. Reaven GM. Insulin resistance: Why is it important to treat? Diabetes Metab. 2001; 27: 247-53.

12. Panchenko EP. Yshemycheskaya bolezn serdtsa y sakharnyy dyabet - kovarnyy tandem [Coronary heart disease and diabetes - an insidious tandem]. Serdtse. 2004; 1(13): 9-12. [Russian]

13. Papanova EY, Korneva KG. Osobennosty arytmyy serdtsa u bolnykh sakharnym dyabetom2 typa [Features of cardiac arrhythmias in patients with type 2 diabetes mellitus]. Klyn medytsyna. 2006; 7: 21-4. [Russian]

14. Kuchulakanti PK, Torguson R, Canos D, Rha SW, Chu WW, Clavijo L, et al. Impact of treatment of coronary artery disease with sirolimus-eluting stents on outcomes of diabetic and nondiabetic patients. Am J Cardiol. 2005 Oct 15 ; 96(8): 1100-6. doi: 10.1016/j.amjcard.2005.06.031

15. Colwell JA; American Diabetes Association. Aspirin therapy in diabetes. Diabetes Care. 2003; 26(Suppl 1): S87-8.

16. Haffner SM; American Diabetes Association. Management of dyslipidemia in adults with diabetes. Diabetes Care. 2003; 26(Suppl 1): S83-6.

17. Heart Outcomes Prevention Evaluation Study Investigators. Effects of ramipril on cardiovascular and microvascular outcomes in people with diabetes mellitus: Results of the HOPE study and MICRO-HOPE substudy. Lancet. 2000; 355: $253-9$

18. UK Prospective Diabetes Study Group. Tight blood pressure control and risk of macrovascular and microvascular complications in type 2 diabetes: UKPDS 38. BMJ. 1998 Sep 12; 317(7160): 703-13.

19. Kessler C, Thomas K, Kao J. Antiplatelet therapy for secondary prevention of acute coronary syndrome, transient ischemic attack, and noncardioembolic stroke in an era of cost containment. J Investig Med. 2012. 60(5): 792-800.

20. Catapano AL, Graham I, De Backer G, Wiklund O, Chapman MJ, Drexel H, et al. 2016 ESC/EAS guidelines for the management of dyslipidaemias. Eur Heart J. 2016; 37: 2999-3058; 
21. Garber AJ, Abrahamson MJ, Barzilay JI, Blonde L, Bloomgarden ZT, Bush MA, et al. Consensus statement by the American Association of Clinical Endocrinologists and American College of Endocrinology on the comprehensive type 2 diabetes management algorithm: 2018 executive summary. Endocr Pract. 2018; 24: 91-120.

УДК 616.1-004-036:616.379-008.64

РОЗВИТОК АТЕРОСКЛЕРОЗУ У ХВОРИХ НА ЦУКРОВИЙ ДІАБЕТ

Журавка Н. В., Шоп І. В., Фолушо Е. T.

Резюме. Особливості розвитку атеросклерозу у хворого на цукровий діабет представлені в цій статті на прикладі клінічного випадку. Атеросклеротичні зміни прогресують не тільки швидше, але й раніше у хворих на цукровий діабет, скорочуючи при цьому тривалість їх життя. Для хворих на діабет характерний підвищений ризик розвитку серцево-судинних захворювань. Особливістю цукрового діабету, що сприяє цьому, є прискорений атеросклероз. У пацієнтів із цукровим діабетом порівняно з пацієнтами без цього захворювання, навіть незважаючи на те, що в крові досягається нормальний рівень холестерину ліпопротеїдів низької щільності, прогресування атеросклеротичних змін пов'язане з поганим контролем глікемії. Найбільшою мірою є ішемічна хвороба серця - найпоширеніша причина смерті в усьому світі. Ішемічна хвороба серця складається з декількох клінічних станів, що характеризуються ішемією міокарда; з іншого боку, коронарна мікросудинна дисфункція, що є умовою порушеного вазомоторного тонусу через декілька механізмів, здатна спровокувати ішемічну хворобу серця, незалежно від наявності атеросклеротичної бляшки. У патогенезі ішемічної хвороби серця беруть участь кілька фракторів ризику серцево-судинної системи. Цукровий діабет вважається одним із найсильніших фракторів ризику серцево-судинних захворювань. Пацієнти з цукровим діабетом мають подвійний ризик розвитку серцево-судинних захворювань. Пацієнти з цукровим діабетом та ішемічною хворобою серця мають більш високу захворюваність і смертність порівняно з пацієнтами без діабету. Оцінюючи значимість гіперглікемії, слід враховувати, що вона рідко виникає за відсутності інших порушень обміну речовин, які мають самостійний вплив на розвиток серцево-судинних захворювань, але в той же час підсилюють один одного несприятливими наслідками і вимагають своєчасної активності виправлення. Ситуація значно погіршується при поєднанні цукрового діабету та артеріальної гіпертензії, особливо за відсутності адекватного лікування.

Ключові слова: ішемічна хвороба серця, цукровий діабет, серцево-судинні фактори ризику, атеросклероз.

УдК 616.1-004-036:616.379-008.64

\section{РАЗВИТИЕ АТЕРОСКЛЕРОЗА У БОЛЬНЫХ С ДИАБЕТОМ}

Журавка Н. В., Шоп И. В, Фолушо Э. Т.

Резюме. Особенности развития атеросклероза у больного сахарным диабетом представлены в этой статье на примере клинического случая. Атеросклеротические изменения прогрессируют не только быстpeе, но и ранее у больных сахарным диабетом, сокращая при этом продолжительность их жизни. Для больных диабетом характерен повышенный риск развития сердечно-сосудистых заболеваний. Особенностью сахарного диабета, способствующего этому, является ускоренный атеросклероз. У пациентов с сахарным диабетом, по сравнению с пациентами без этого заболевания, даже, несмотря на то, что в крови достигается нормальный уровень холестерина липопротеидов низкой плотности, прогрессирование атеросклеротических изменений связано с плохим контролем гликемии. Ишемическая болезнь сердца - самая распространенная причина смерти во всем мире. Ишемическая болезнь сердца состоит из нескольких клинических состояний, характеризующихся ишемией миокарда; с другой стороны, коронарная микрососудистая дисфункция, является условием нарушенного вазомоторного тонуса и способна спровоцировать ишемическую болезнь сердца, независимо от наличия атеросклеротической бляшки. В патогенезе ишемической болезни сердца принимают участие несколько фракторов риска сердечнососудистой системы. Сахарный диабет считается одним из самых сильных факторов риска сердечнососудистых заболеваний. Пациенты с сахарным диабетом имеют двойной риск развития сердечнососудистых заболеваний. Пациенты с сахарным диабетом и ишемической болезнью сердца имеют более высокую заболеваемость и смертность по сравнению с пациентами без диабета. Оценивая значимость гипергликемии, следует учитывать, что она редко возникает при отсутствии других нарушений обмена веществ, имеющих самостоятельный влияние на развитие сердечно-сосудистых заболеваний, но в то же время усиливают друг друга неблагоприятными последствиями и требуют своевременной тактики лечения. Ситуация значительно ухудшается при сочетании сахарного диабета и артериальной гипертензии, особенно при отсутствии адекватного лечения.

Ключевые слова: ишемическая болезнь сердца, сахарный диабет, сердечно-сосудистые фракторы риска, атеросклероз.

The authors of this study confirm that the research and publication of the results were not associated with any conflicts regarding commercial or financial relations, relations with organizations and/or individuals who may have been related to the study, and interrelations of coauthors of the article.

Стаття надійшла 16.05 .2020 р. Рекомендована до друку на засіданні редакційної колегії після рецензування 